\title{
Intra-arterial thrombolysis for tandem cervical internal carotid artery/middle cerebral artery occlusion approached from the contralateral side
}

\author{
Masashi Nakatsukasa, Joji Inamasu, Takumi Kuramae, Katsuya Saito
}

\begin{abstract}
Despite the widespread use of intravenous (IV) thrombolysis for acute stroke, patients with occlusion of the internal carotid artery (ICA) are often refractory to the intervention. Recent studies suggest that intra-arterial (IA) thrombolysis may be more efficacious than IV thrombolysis for ICA occlusion. Tandem occlusion of the ICA and middle cerebral artery (MCA) is particularly challenging, because of difficulty in achieving recanalization due to long-segment thrombus. The use of new endovascular devices to mechanically remove clots may be promising, but they are neither universally available nor evidence-based. We present a case of tandem left ICA/MCA occlusion treated by IA thrombolysis through the anatomical collateral pathway. The MCA occlusion was approached from the contralateral ICA through the anterior communicating artery. The recanalization of both the MCA and ICA was accomplished, followed by prompt clinical improvement. This may be a useful IA thrombolysis technique for selected patients with tandem ICA/MCA occlusion in whom collateral circulation is developed enough to be catheterized.

(¥JJAAM 2008; 19: 1052-6)

Keywords: thrombolytic therapy, acute cerebral ischemia, collateral pathway

Accepted for publication on July 10, 2008 (08-054)
\end{abstract}

\section{Introduction}

Despite the widespread use of intravenous (IV) thrombolysis for acute stroke, patients with occlusion of the internal carotid artery (ICA) are often resistant to the intervention and have a suboptimal prognosis. Tandem occlusion of the ICA and middle cerebral artery (MCA) is particularly challenging, because of its long-segment thrombus and difficulty in achieving recanalization. We present a case of tandem left cervical ICA/MCA occlusion treated by intra-arterial (IA) thrombolysis approached from the contralateral side through the anatomical collateral pathway.

\section{Case Report}

A previously healthy right-handed 58-year-old man suddenly became aphasic, and he was brought to our institution 210 min after onset. On arrival, his consciousness level

Address correspondence to:

Joji Inamasu, MD, PhD.

Department of Neurosurgery, Saiseikai Utsunomiya Hospital

911-1 Takebayashi, Utsunomiya, Tochigi 321-0974 was E2V1M5 on the Glasgow Coma Scale, and right-sided hemiplegia was present. He had no history of cardiac arrhythmia, and electrocardiogram showed a sinus rhythm of 72 beats per minute. Acute cerebral ischemia of the dominant hemisphere was suspected. Brain computed tomography (CT) scan revealed a hyperdense sign of the left MCA (Fig. 1a), but, there was no evidence of early ischemic change. Diffusion-weighted image of the brain magnetic resonance (MR) imaging showed a hyperintense area in the left basal ganglia, but the cerebral cortex was intact (Fig. 1b). The patient was out of indication for IV thrombolysis since he was brought to the hospital more than 3 hours after onset. Therefore, we decided to treat him with intra-arterial (IA) thrombolysis after thorough discussion with his family. He was taken to an angiographic suite: the door-to-needle time was $70 \mathrm{~min}$ and his pre-procedural National Institute of Health Stroke Scale (NIHSS) score was 28 points. Since there were no signs of airway obstruction, the procedure was performed under local anesthesia supplemented by mild IV sedation so that his neurological status could be evaluated instantaneously. Left common carotid angiography showed occlusion of the left cervical ICA (Fig. 2a). He was diagnosed with left ICA/ MCA tandem occlusion, and anterograde catheterization 


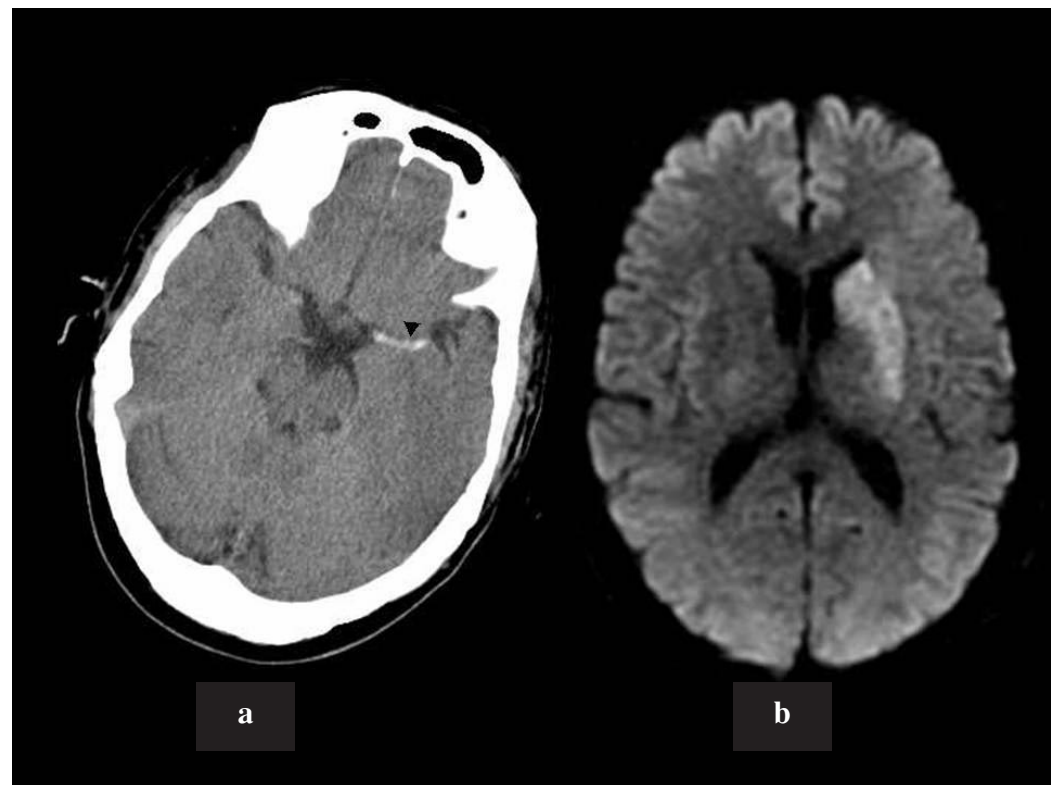

Fig. 1.

a: CT scan immediately after arrival showing a hyperdense sign of the left MCA (arrowhead).

b: Diffusion-weighted MR imaging showing an area of early ischemia in the anterior part of the left basal ganglia.

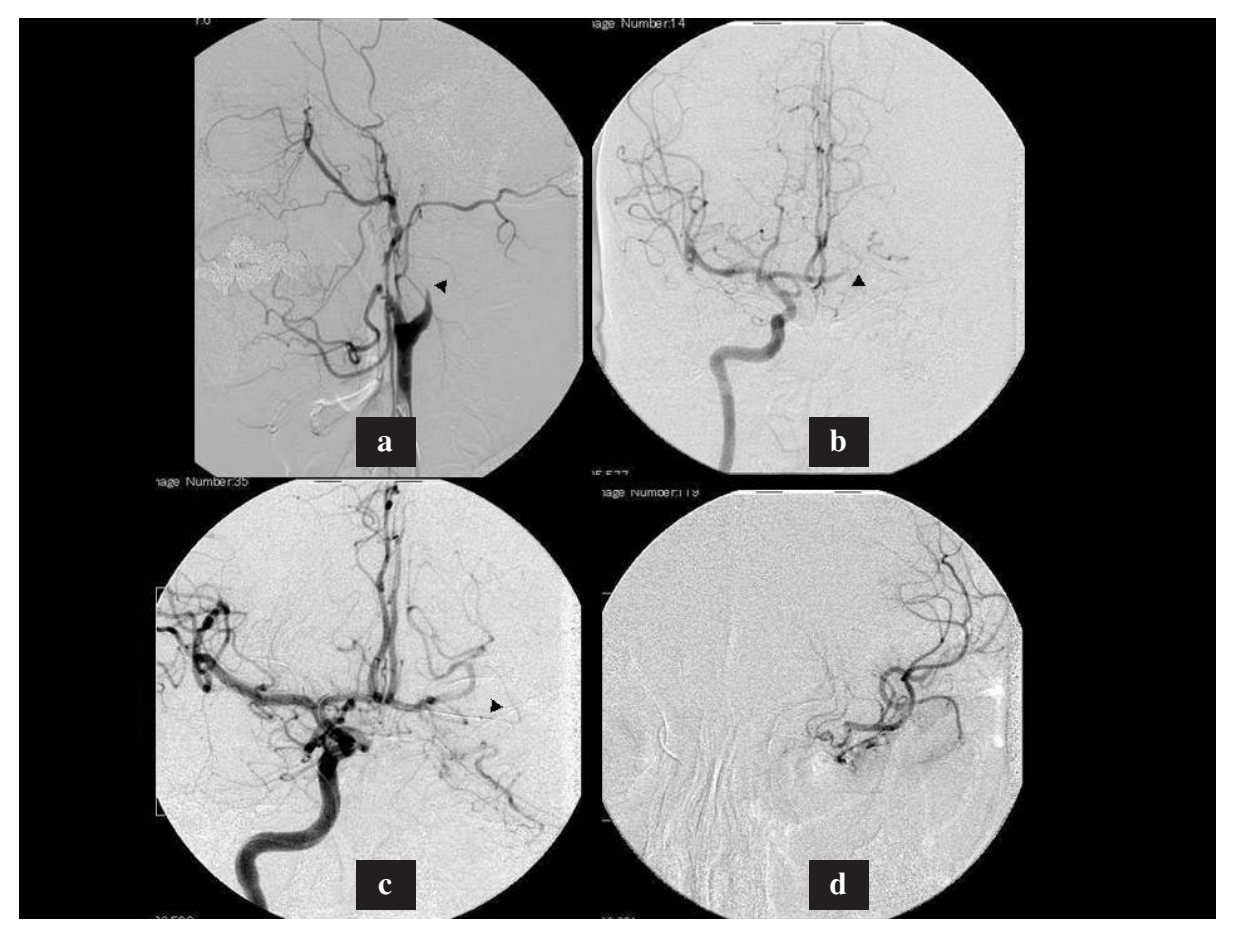

Fig. 2.

a: Left common carotid angiography (lateral view) showing occlusion of the left cervical ICA (arrowhead).

b: Right internal carotid angiography (AP view) showing patent ACoA and left ACA (arrowhead), although left MCA was not opacified.

c: A microcatheter (arrowhead) navigated into the left MCA through ACoA.

$\mathrm{d}$ : Good recanalization of the left MCA was achieved after local thrombolysis. 


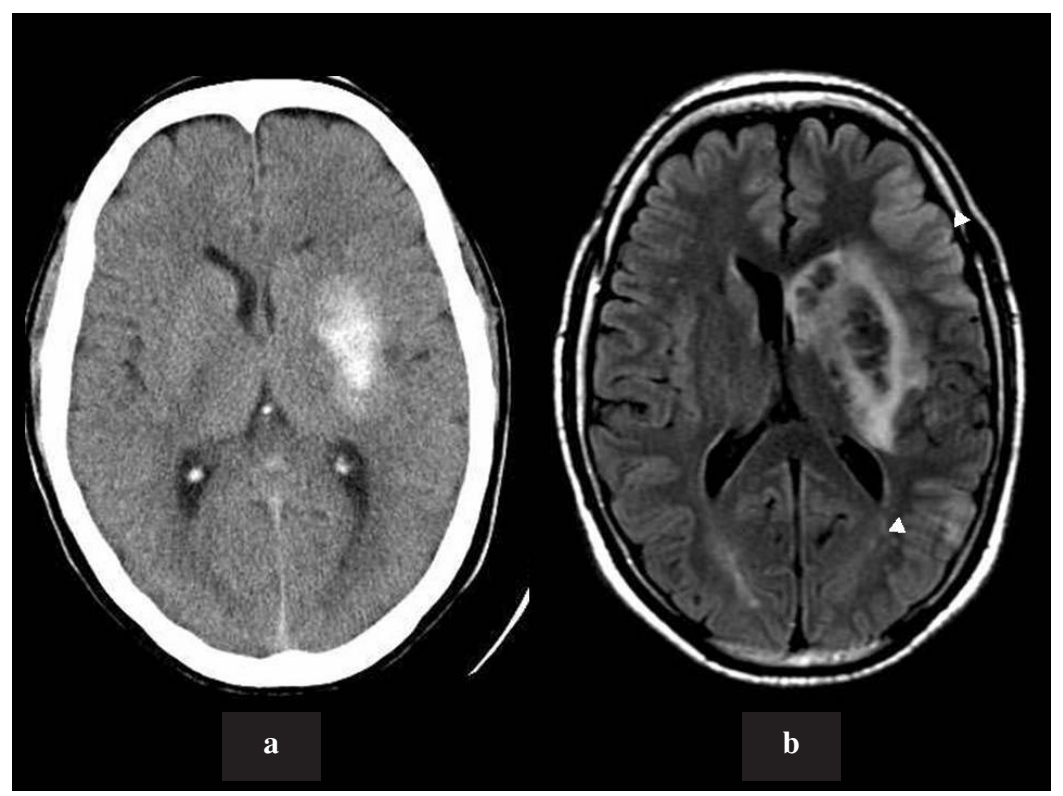

Fig. 3.

a: CT scan $24 \mathrm{~h}$ after thrombolysis showing high density area in the left basal ganglia, which was a mixture of infarct and contrast material extravasation.

b: MR imaging showing an infarction in the left basal ganglia and limited volume of water-shed cortical infarct (arrowheads).

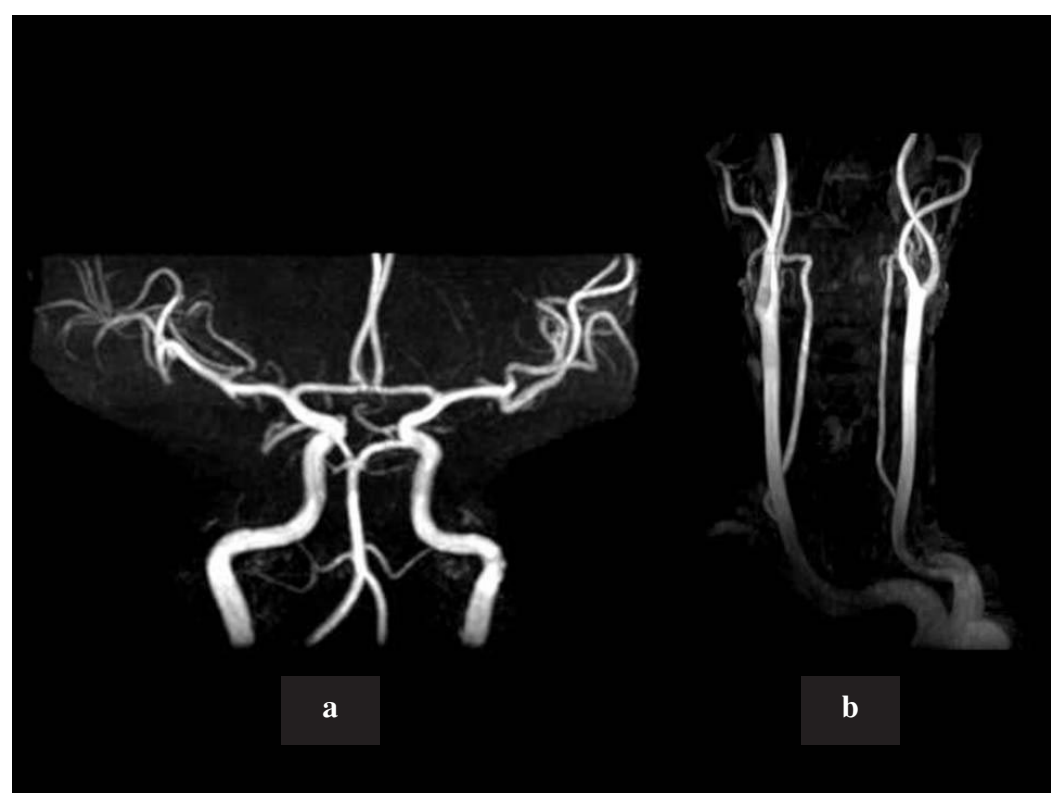

Fig. 4.

a: Brain MR angiography showing recanalization of the left MCA.

b: Cervical MR angiography showing recanalization of the left ICA.

through the long-segment thrombus was not attempted for fear of complications from distal embolic migration or arterial dissection. The anterior communicating artery (ACoA) as well as left anterior cerebral artery (ACA) re- mained open (Fig. 2). First, a 2.5- Fr Renegade 18 microcatheter (Boston Scientific, Natic, USA) was inserted into a 6- Fr Envoy guiding catheter (Cordis, Miami, USA) placed in the right ICA. Subsequently, the microcatheter 
was advanced to the left ICA bifurcation through the ACoA, and navigated further into the left MCA M1 distal segment using a Transcend microguidewire (Boston Scientific) (Fig. 2c). Urokinase (360,000 IU) was infused for more than $30 \mathrm{~min}$ using a microcatheter. Contrast agent injection after infusion revealed recanalization of the left MCA (Fig. 2d). Finally, the microcatheter was pulled back from the distal M1 to the left ICA bifurcation, and an additional 240,000 IU of urokinase was administered. The total procedural time was $120 \mathrm{~min}$. Within $30 \mathrm{~min}$ after thrombolysis, he could move his right extremities, and his NIHSS score improved to 15 points on the next day. Both $\mathrm{CT}$ and MR imaging were taken 24 hours after thrombolysis. The high-density area on CT in the left basal ganglia reflected a mixture of infarct and contrast extravasation (Fig. 3a). Although MR imaging (fluid attenuated inversion recovery image) showed an additional small water-shed infarct in the left frontal lobe (Fig. 3b), the great majority of the left cerebral cortex was spared from ischemia. Follow-up MR angiography 3 days after thrombolysis showed recanalization of the left MCA (Fig. 4a) and cervical ICA (Fig. 4b).

\section{Discussion}

Despite lack of class I evidence, IA thrombolysis has repeatedly been shown to be a promising option for acute cerebral ischemia, particularly in those seeking medical attention more than 3 hours after onset in whom therapeutic window of opportunity has passed and IV thrombolysis is not indicated ${ }^{1)}$. The optimal candidates for IA thrombolysis may be those with a distal M1 or proximal M2 embolic occlusion of the $\mathrm{MCA}^{1,2)}$. Studies show that the outcome of IA thrombolysis is suboptimal for patients with acute ICA occlusion ${ }^{1)}$. When ICA occlusion coincides with MCA occlusion, i.e., tandem ICA/MCA occlusion, the outcome seems to be worse ${ }^{1,2)}$. Attempts to pharmacologically recanalize tandem occlusions that harbor massive arterial thrombus have limitations: however, with the recent technological advancements in interventional radiology, including mechanical thrombectomy device, balloon angioplasty, and emergency stenting, the treatment outcome for tandem lesions seems to have improved ${ }^{1-3)}$. The use of such techniques has not been based on sufficient evidence and is not authorized unconditionally in several countries ${ }^{3)}$.

The present case demonstrates a successful attempt of IA thrombolysis for tandem ICA/MCA occlusion approached from the contralateral side. The patient had ini- tially been diagnosed with MCA occlusion based on symptoms and a hyperdense sign on CT. Although ultrasound studies were not performed, IA thrombolysis for MCA occlusion had been planned. The occlusion of the cervical ICA was unexpected, and we were concerned about the risk associated with anterograde catheterization through the long-segment thrombus. Lack of availability of mechanical clot removal devices or emergency carotid stenting was another reason why anterograde catheterization was not attempted. Thrombolysis of the left MCA occlusion approached from the contralateral ICA through the ACoA was considered feasible after angiography showed a patent ACoA, left ACA and rich collateral circulation. It is difficult to explain why the cervical ICA became recanalized after thrombolysis because the vessel was untreated during the procedure. The cause of stroke was also unidentified despite vigorous search after thrombolysis. Lack of residual stenosis on follow-up cervical MR angiography, together with absence of underlying cardiac arrhythmia, suggests that temporary vasospasm of the cervical ICA may have elicited local thrombus formation, followed by anterograde propagation of the thrombus into the $\mathrm{MCA}^{4}$.

For patients with tandem ICA/MCA occlusion, this approach utilizing the anatomical collaterals has several potential advantages over the anterograde catheterization. First, there is no need for microcatheters to penetrate longsegment thrombus, and complications resulting from distal clot migration or arterial dissection could be avoided. Second, the amount of thrombolytic agents required to achieve recanalization may be smaller in this approach than that required in the anterograde approach because of larger amount of thrombus encountered until reaching to the target lesion in the latter, which in turn may lead to a lower incidence of hemorrhagic transformation. IA thrombolysis through the collateral pathways of the circle of Willis has been reported only occasionally ${ }^{5,6}$. Such collateral pathways, in most instances the $\mathrm{ACoA}^{4)}$ or a posterior communicating artery ${ }^{6}$, have many anatomic variations, and navigating microcatheters through anomalous vessels might be a difficult task even for experienced hands.

In summary, this is a feasible IA thrombolysis technique for tandem ICA/MCA occlusion in those with rich collateral circulations. This procedure is particularly useful if mechanical clot removal devices or emergency carotid stenting are unavailable. 


\section{References}

1) Dabitz R, Triebe S, Leppmeier U, et al: Percutaneous recanalization of acute internal carotid artery occlusions in patients with severe stroke. Cardiovasc Intervent Radiol 2007; 30: $34-41$.

2) Flint AC, Duckwiler GR, Budzik RF, et al: Mechanical thrombectomy of intracranial internal carotid occlusion: pooled results of the MERCI and Multi MERCI Part I trials. Stroke 2007; 38: 1274-80.

3) Pelz DM, Levy EI, Hopkins LN: Advances in interventional neuroradiology 2007. Stroke 2008; 39: 268-72.
4) Arning C, Schrattenholzer A, Lachenmayer L: Cervical carotid artery vasospasms causing cerebral ischemia: detection by immediate vascular ultrasonographic investigation. Stroke 1998; 29: 1063-6.

5) Kanazawa R, Kominami S, Yoshida Y, et al: Middle cerebral artery thrombolysis through the contralateral internal carotid artery--case report. Neurol Med Chir (Tokyo) 2004; 44: 3725.

6) Kole MK, Pelz DM, Lee DH, et al: Intra-arterial thrombolysis of embolic middle cerebral artery using collateral pathways. Can J Neurol Sci 2005; 32: 257-60.

症例報告

\title{
頸部内頸動脈〜中大脳動脈への連続性動脈閉塞に対し, 健側より経動脈的血栓溶解療法を行った 1 例
}

\author{
中務 正志稲桝 丈司倉前卓美斉藤 克也
}

要旨 脳梗塞超急性期治療において, 近年では経静脈的血栓溶解療法が目覚しい効果をあげつつある。にもかか わらず，急性内頸動脈閉塞による脳梗塞患者の予後は依然として不良である。急性内頸動脈閉塞症に関しては経 静脈的よりむしろ経動脈的血栓溶解療法がより有効ではないかという意見もある。急性内頸動脈閉塞症の中でも， 頸部内頸動脈〜中大脳動脈にかけての連続性閉塞は血栓内にカテーテルを通すこと自体にリスクがあり, 治療が 困難と考えられてきた。海外では新しい血管内治療デバイスも各種考案されているが，その安全性は十分に確立 されていない。今回我々は, 健側よりアプローチし側副血行路を介し病変部に到達, 経動脈的血栓溶解療法を行っ た左頸部内頸動脈〜中大脳動脈連続性閉塞の 1 例を経験したので報告する。本例では，健側の内頸動脈に親カテー テルを留置した後マイクロカテーテルを前交通動脈経由で患側の中大脳動脈閉塞部まで進め, 同部より血栓溶解 剤 (ウロキナーゼ) を注入した。中大脳動脈のみならず頸部内頸動脈閉塞部の再開通が得られ, 臨床上も著明な 改善を認めた。本治療法の適応症例は限られるが，経静脈的血栓溶解療法の夕イムリミット（発症より 3 時間以 内) が経過していても, 側副血行路がよく発達しマイクロカテーテルの挿入が可能と思われる症例に㧍いては施 行する価值のある治療法と考えられる。

(日救急医会誌 $2008 ； 19 ： 1052-6$ )

キーワード・血栓溶解療法, 急性脳虚血, 側副血行路

済生会宇都宮病院脳神経外科

著者連絡先：干 321-0974 栃木県宇都宮市竹林町 911-1／原稿受理日：2008 年 7 月 10 日（08-054） 